\title{
Sideroblastic anaemia in adult coeliac disease
}

\author{
A. M. DAWSON, C. D. HOLDSWORTH, AND C. S. PITCHER \\ From the Departments of Medicine and Pathology, \\ Royal Free Hospital, London
}

\begin{abstract}
EDITORIAL SYNOPSIS Anaemia due to pyridoxine deficiency has not previously been described in adult coeliac disease. The patient described here had a sideroblastic bone marrow showing the characteristic perinuclear rings of iron-containing granules and biochemical evidence of pyridoxine deficiency. These changes disappeared completely when the patient was put on a gluten-free diet.
\end{abstract}

A dimorphic or hypochromic anaemia associated with a sideroblastic bone marrow, showing charateristic perinuclear rings of iron-containing granules, has been referred to as refractory sideroblastic anaemia (Heilmeyer, Keiderling, Bilger, and Bernauer, 1958) or refractory normoblastic anaemia (Dacie, Smith, White, and Mollin, 1959). In some patients there is an obvious family history while in others the condition has been found in association with other diseases (Bowman, 1961). The condition is usually refractory to treatment, but a few patients respond to pyridoxine (Mollin and Dacie, 1960) and it is probable that all patients with pyridoxineresponsive anaemia show this haematological picture. The cause of the condition is unknown but even when a response to pyridoxine occurs the abnormality persists with hypochromic cells in the peripheral blood and sideroblasts in the marrow (Mollin and Dacie, 1960). It seems unlikely that these patients have a dietary deficiency of the vitamin and it has been postulated that there is an excessive demand for pyridoxine by certain reactions pertaining to haemoglobin synthesis, giving rise to a condition comparable with the relative deficiency of folic acid which occurs in patients with haemolytic anaemia (Dacie et al., 1959; Ernslev, Lear, and Castle, 1960). Other manifestations of pyridoxine deficiency are not seen in these patients. Although adult coeliac disease may give rise to a variety of nutritional disturbances, deficiencies of water-soluble vitamins apart from folic acid and $\mathrm{B}_{12}$ are considered to be rare and to date there have been no reports of clinical pyridoxine deficiency occurring in this condition. We therefore report the following patient who, as part of a severe nutritional disorder secondary to adult coeliac disease, had a refractory hypochromic anaemia associated with a sideroblastic bone marrow showing typical perinuclear ring forms and biochemical evidence of pyridoxine deficiency. These changes disappeared completely when she was treated with a gluten-free diet.

\section{CASE REPORT}

The patient was a 46-year-old married woman who was admitted to the Royal Free Hospital in September 1962. For three years she had been vaguely unwell but before this had been well all her life. She had always been rather small but there had never, until very recently, been any bowel disturbances. In January 1962, when admitted to her local hospital for investigation of a vaginal discharge, she was found to have a macrocytic anaemia. Curettage of the uterus was performed and she was transfused with 2 pints ( 1.2 litres) of blood. A barium meal and followthrough and faecal fat estimation were normal.

Two months later, in April 1962, she was admitted to another hospital with complaints of breathlessness and palpitations on exertion. She was a little pigmented and had lost some weight. A macrocytic anaemia was again found and the marrow was megaloblastic. In view of the pigmentation, a marrow film was stained for iron but it was reported that no excess was present. The serum vitamin $\mathbf{B}_{12}$ level was normal but the serum folic acid was low and on oral folic acid the haemoglobin rose from 8 to $13 \mathrm{~g}$. per $100 \mathrm{ml}$. Within a month, however, persistent loose stools with colicky hypogastric pain developed accompanied by some nausea and vomiting. The patient attributed this to the folic acid tablets and stopped taking them. On re-admission to hospital in June 1962, the most marked features were deepening pigmentation and intermittent fever rising as high as $102^{\circ} \mathrm{F}$. $\left(39^{\circ} \mathrm{C}\right.$.) which did not respond to repeated courses of antibiotics but remitted spontaneously after four weeks. Investigations again included a normal barium series and treatment on this occasion included parenteral folic acid and also intramuscular iron in the form of an iron-sorbitol-citrate complex (Jectofer). The amount of iron that was given is not clear but it was not less than $10 \mathrm{~g}$. She was discharged on August 15 1962, a little improved, but was re-admitted with a recurrence of diarrhoea, pyrexia, and abdominal 
pain two weeks later. She was more ill and had oedema of all limbs and of the sacrum. Two days later she was transferred to the Royal Free Hospital.

On admission, she was an emaciated ill woman weighing only $5 \mathrm{st} .9 \mathrm{lb}$. (36 kg.) in spite of generalized pitting oedema. The history obtained was vague and it subsequently became clear that she remembered nothing of her first days in hospital. The skin was generally pigmented, scaly, and cracked (eczema craquele) resembling that of a woman of 70 (Wells, 1962). Ecchymoses and purpura resembling senile purpura were present in the right arm. The pulse was 78 and the blood pressure $110 / 70 \mathrm{~mm}$. Hg. There was clinical evidence of a right pleural effusion and slight ascites. There was no glossitis.

INVESTIGATIONS Haemoglobin $7 \cdot 3$ g. per $100 \mathrm{ml}$., haematocrit $30 \%$ M.C.H.C. $24 \%$, red cell count 3,200,009 per c.mm., M.C.V. $94 \mathrm{c} \mu$, leucocytes 7,300 per c.mm., reticulocytes $3.3 \%$. The peripheral blood film showed a dimorphic picture with approximately $20 \%$ of hypochromic cells present, the remainder being normochromic. There was some anisocytosis. The direct antiglobulin (Coombs) test was negative. The bone marrow showed a well-developed normoblastic hyperplasia and the cytoplasm of many of the red cell precursors showed defective haemoglobinization, vacuolation, and the presence of basophilic stippling. Iron stains on the marrow showed a great excess of interstitial and reticuloendothelial iron, and in addition, many abnormal sideroblasts were present with characteristic perinuclear iron granules (Fig. 1). The serum iron was $48 \mu \mathrm{g}$. per $100 \mathrm{ml}$. and the serum total iron-binding capacity $168 \mu \mathrm{g}$. per $100 \mathrm{ml}$. Serum vitamin $B_{12}$ was $900 \mu \mu \mathrm{g}$. per ml. (normal 150-900 $\mu \mu \mathrm{g}$. per ml.) and the serum folic acid $1.2 \mathrm{~m} \mu \mathrm{g}$. per $\mathrm{ml}$. (normal $6-20 \mathrm{~m} \mu \mathrm{g}$. per $\mathrm{ml}$.).

Urinary excretion of xanthurenic acid was $23 \mathrm{mg}$. per 24 hours, but after a loading dose of $4 \mathrm{~g}$. of 1-tryptophan, it rose to $60 \mathrm{mg}$. per 24 hours (normal up to $20 \mathrm{mg}$. per 24 hours).

Serum total protein $3.2 \mathrm{~g}$. per $100 \mathrm{ml}$. (albumin $1.5 \mathrm{~g}$. and globulin $1.7 \mathrm{~g}$. per $100 \mathrm{ml}$.). After ${ }^{131}$ I-labelled P.V.P. was given intravenously, $5.6 \%$ of the dose was excreted in the stools in four days (normal up to $1.5 \%$ ). This suggests that part of the hypoalbuminaemia was due to intestinal protein loss. Serum calcium $6.7 \mathrm{mg}$. per $100 \mathrm{ml}$. serum phosphorus $3 \cdot 1 \mathrm{mg}$. per $100 \mathrm{ml}$. Serum alkaline phosphatase 30 King-Armstrong units per $100 \mathrm{ml}$. Serum carotene $4 \mu \mathrm{g}$. per $100 \mathrm{ml}$., serum cholesterol $65 \mathrm{mg}$. per $100 \mathrm{ml}$.

Fasting blood sugar was $74 \mathrm{mg}$. per $100 \mathrm{ml}$. and after $50 \mathrm{~g}$. of glucose orally, blood sugar levels at 30-minute intervals were $94,100,121$, and $113 \mathrm{mg}$. per $100 \mathrm{ml}$. Urinary excretion in first five hours after an oral dose of $25 \mathrm{~g}$. of d-xylose was low (0.5 g.). Faecal fat excretion on a diet containing only $30 \mathrm{~g}$. of fat per day averaged 7 g. per day.

The chest radiograph showed a small right pleural effusion.

A small bowel meal showed no local anatomical defect but there were generalized changes compatible with a severe steatorrhoea. The jejunal biopsy when examined under the dissecting microscope showed complete

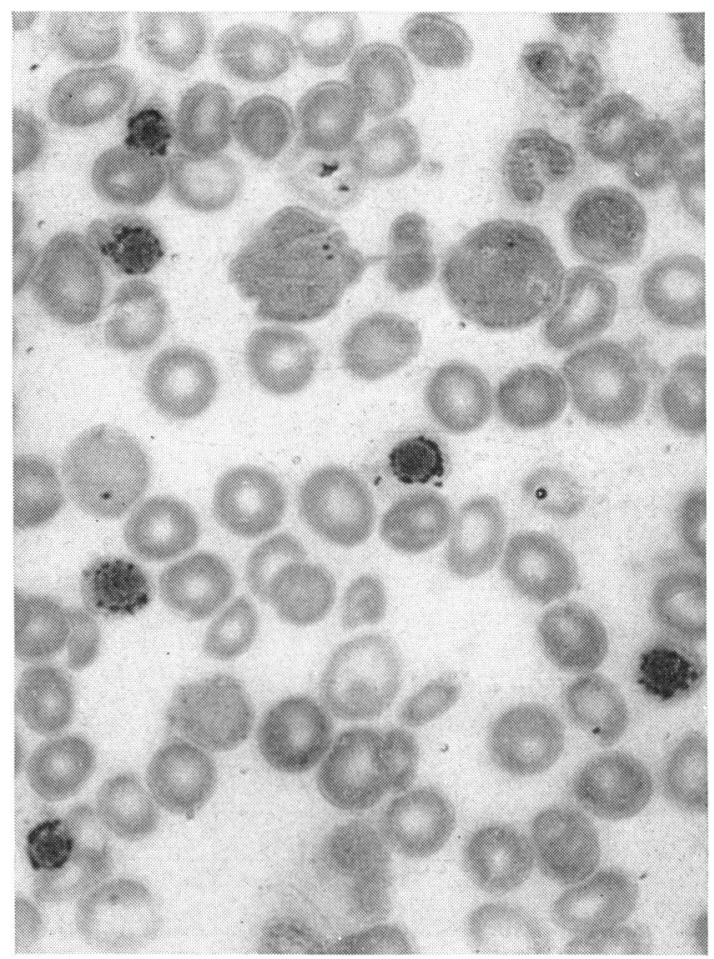

FIG 1. Sternal marrow film showing sideroblasts (Perls's iron stain).

absence of villi with a mosaic appearance. On histological section there was total villous atrophy.

A liver biopsy showed that the liver cells and portal areas contained a great excess of iron and much lipofuscin but there was no evidence of cirrhosis and only minimal fibrosis.

A diagnosis of adult coeliac disease with gross malnutrition and an associated sideroblastic anaemia was made.

TREATMENT A low-sodium diet (22 mEq. per day) and diuretics (chlorothiazide $2 \mathrm{~g}$. daily) caused a rapid diuresis and the patient's weight fell to $3 \mathrm{st} .11 \mathrm{lb}$. (24 kg.). A gluten-free diet with folic acid supplements $(15 \mathrm{mg}$. per day) produced a dramatic remission (Fig. 2). Within three days she became mentally alert and her appetite returned. From then on there was a steady gain in weight. Within two weeks, a repeat of the xylose absorption test showed a urinary excretion of $3.7 \mathrm{~g}$., the serum albumin had risen to $2 \cdot 5 \mathrm{~g}$. per $100 \mathrm{ml}$, the P.V.P. excretion fell to $2.4 \%$ of the intravenous dose, and there was an improvement in the histology of a jejunal biopsy as shown by the more columnar nature of the surface epithelial cells. By the time of discharge two months later her weight had increased to $6 \mathrm{st} .8 \mathrm{lb}$. (42 kg.). By February 1963, she weighed $8 \mathrm{st} .4 \mathrm{lb}$. (53 kg.). During this period her skin had returned to that of a normal 40-year-old woman. A jejunal biopsy at this time showed on the dissecting 


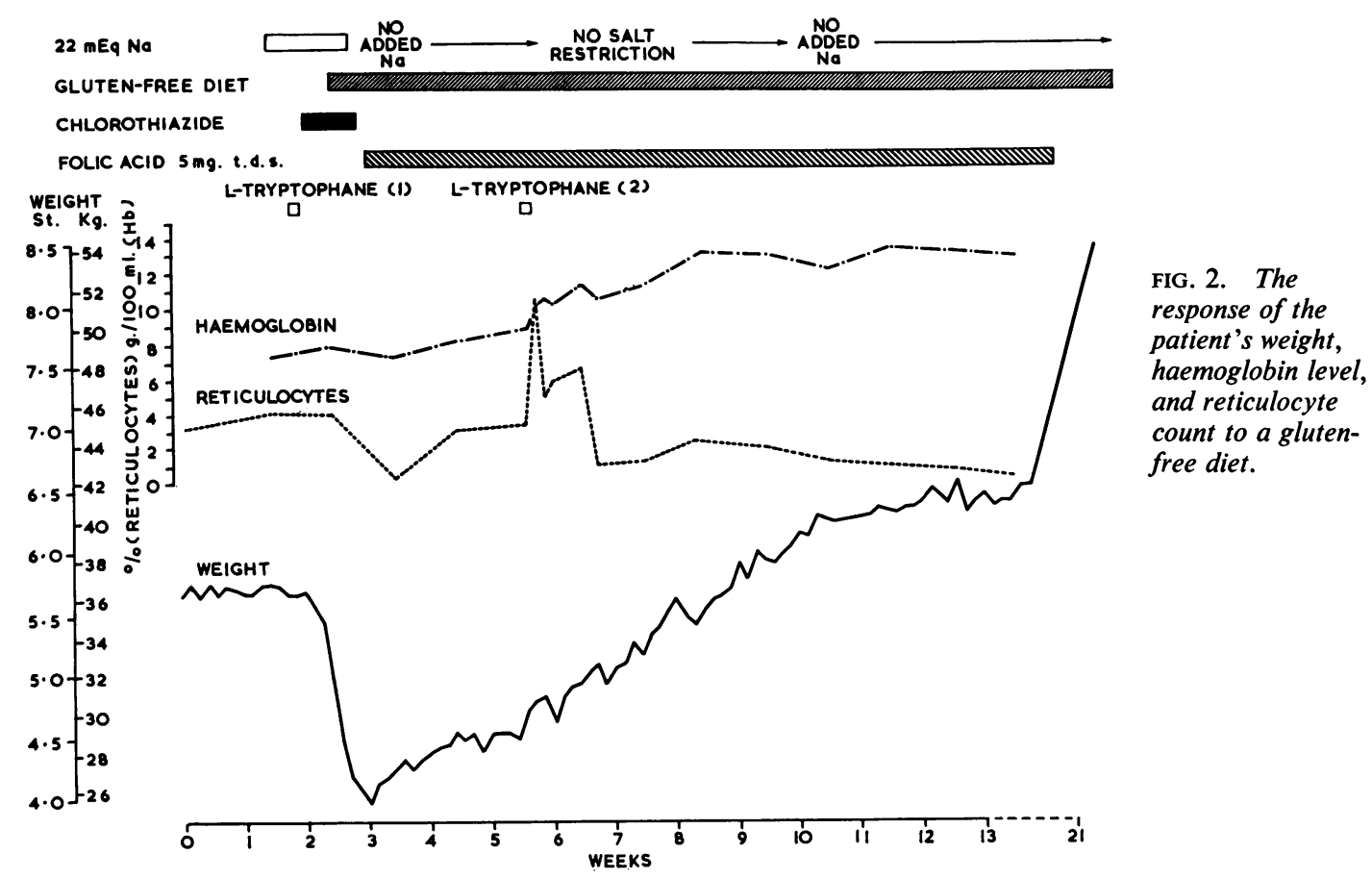

microscope that there were attempts at villous growth and on histological section the epithelial cells were apparently normal.

haEMATOlogical CHANGE On a gluten-free diet, the haemoglobin rose steadily. A further sternal marrow examination on the fifteenth day of the gluten-free diet showed a definite reduction in the amount of stainable iron in the red cell precursors, and there was an improvement in the haemoglobinization of their cytoplasm. A reticulocyte crisis occurred, with a peak on the 23rd day after the diet was instituted, and on this day the urinary xanthurenic acid excretion after a tryptophan load had returned to normal ( $8 \mathrm{mg}$. in 24 hours). During this period, the hypochromic cells gradually disappeared from the blood and the M.C.H.C. rose to $30 \%$. A further marrow specimen was obtained 42 days after starting the diet and showed completely normal erythropoiesis with no excess of stainable iron in the normoblasts, although the great excess of interstitial iron was still present. At the time of discharge, after some 12 weeks on the diet, her haemoglobin was $13.2 \mathrm{~g}$. per $100 \mathrm{ml}$. and the peripheral blood film was entirely normal. The initially low platelet count rose as haematological improvement occurred and ranged between 300,000 and 500,000 per c.mm.

The initially low serum iron remained in the region of $50 \mu \mathrm{g}$. per $100 \mathrm{ml}$. until the $34 \mathrm{th}$ day of the gluten-free diet, when it had risen to $90 \mu \mathrm{g}$. per $100 \mathrm{ml}$. with a total iron-binding capacity of $260 \mu \mathrm{g}$. per $100 \mathrm{ml}$. Nine days later it had risen to $170 \mu \mathrm{g}$. per $100 \mathrm{ml}$. with a binding capacity of $275 \mu \mathrm{g}$. per $100 \mathrm{ml}$. When the patient was seen again in February 1963, the serum iron was $165 \mu \mathrm{g}$. and the binding capacity $360 \mu \mathrm{g}$. per $100 \mathrm{ml}$.

\section{DISCUSSION}

This patient was a severe example of malnutrition due to adult coeliac disease who had typical intestinal biopsy findings and showed an excellent response to a gluten-free diet. In addition, she had a reversible sideroblastic anaemia which disappeared completely during treatment with the gluten-free diet, suggesting that it was due to some nutritional deficiency. Complete remission of a sideroblastic anaemia, with disappearance of both hypochromic cells from the peripheral blood and sideroblasts from the bone marrow, has not previously been recorded and, although in one of the patients described by Mollin and Dacie (1960), the haemoglobin rose to normal after treatment with pyridoxine both hypochromia and sideroblastic changes persisted.

It is difficult to be sure of the pathogenesis of the sideroblastic anaemia in this patient but there is strong circumstantial evidence that it was due to pyridoxine deficiency. She had pyridoxine deficiency as judged by the abnormal tryptophan load test and this was normal when repeated at the time of 
the reticulocyte response. Furthermore, the haematological changes were almost identical with those described in cases of pyridoxine-responsive anaemia. Features particularly suggestive of the condition were the dimorphic appearance of the peripheral blood film with numerous hypochromic cells, the pale, vacuolated, stippled and defectively haemoglobinized red cell precursors in the marrow, and the characteristic perinuclear iron-containing granules in these cells. A reticulocyte crisis occurred three weeks after starting the gluten-free diet and this would suggest repletion of a deficiency state. It certainly did not represent folic acid repletion as it occurred too late after starting oral folic acid, and although there was biochemical evidence of folic acid depletion this was not manifested by morphological changes in either the myeloid or erythroid precursors in the bone marrow: indeed, the bone marrow findings were quite unlike those of folic acid deficiency. A slightly raised reticulocyte count was present and this is not usually seen in refractory sideroblastic anaemia but is reported in pyridoxine-deficient mice (Mirone and Jackson, 1959). It was impossible to obtain conclusive proof that pyridoxine alone had caused the blood changes for this would have entailed observing the haematological response to pyridoxine alone while the patient was on a normal diet. This could not be done since the patient was dangerously ill and the gluten-free diet had to be exhibited as soon as the diagnosis of adult coeliac disease had been established.

Pyridoxine deficiency giving rise to symptoms in man is thought to be rare and anaemia is not a common feature. Infants fed on artificial milk inadvertently low in pyridoxine may have convulsions (Molony and Parmelee, 1954). The peripheral neuropathy seen in patients taking isoniazid is thought to be due to the pyridoxine-antagonistic effect of this drug but a sideroblastic anaemia has only twice been reported in association with isoniazid treatment (Bowman, 1961; Kohn, Heilmeyer, and Clotten, 1963). Adults on a low pyridoxine diet or when taking the pyridoxine antagonist 4-desoxypyridoxine may show an abnormal response to a tryptophan load and a low blood pyridoxine without there being overt clinical manifestations, though some patients develop seborrhoeic dermatitis (Mueller and Vilter, 1950) and also mild lymphopenia. These mild manifestations may be due to the relatively brief period of induced deficiency as compared with the long-term animal experiments where more impressive manifestations of deficiency are seen (Follis, 1958). An abnormal tryptophan load test in the absence of clinical features of pyridoxine deficiency has been found in conditions in which the demands for pyridoxine are presumed to be high, as in pregnancy (Wachstein and Lobel, 1954) and in diabetes (Rosen, Maengwyn-Davies, Becker, Stone, and Friedenwald, 1955). It is possible that this increased demand occurs in a wide variety of metabolic disorders for pyridoxine is a ubiquitous cofactor which in vitro is essential for at least 12 types of enzyme reaction (Braunstein, 1960). Pyridoxine, which is the free alcohol, is probably metabolically inert and has to be converted either to pyridoxal phosphate (the phosphorylated aldehyde formed by an enzymatic reduction) or to pyridoxamine phosphate, the phosphorylated amine. There is little information on the form of vitamin $B_{6}$ in the diet but Rabinowitz and Snell (1948) found that $80 \%$ was present as a bound form (presumably phosphate) of the aldehyde or amine. The mechanism of absorption of these forms has not been studied; the free alcohol probably diffuses across the intestinal mucosa (Booth and Brain, 1962) and this process may be slightly depressed in adult coeliac disease (Brain, Stewart, and Booth, 1963) but it is unknown whether the other forms are hydrolyzed before or during absorption or also diffuse unchanged. Thus, although pyridoxine fed as an aqueous solution may be well absorbed from the jejunum, it would be dangerous to extrapolate these findings to dietary vitamin $B_{6}$. At one time it was said that watersoluble vitamin deficiency was rare in idiopathic steatorrhoea but it is now known that folic acid deficiency is almost the hallmark of the disorder (Girdwood, 1959). Recently biochemical evidence of pyridoxine deficiency was reported in patients with adult coeliac disease by Kowlessar, Haeffner, Benson, and Sleisenger (1961) who found an increased excretion of xanthurenic acid and other tryptophan metabolites after tryptophan loading. No clinical or haematological stigmata were observed.

Anaemia due to pyridoxine deficiency has not previously been described in adult coeliac disease but it is possible that the characteristic sideroblastic changes in the marrow are not found when the body iron stores are depleted as is often the case in malabsorptive states. It is probable that this condition would not have been suspected in this patient unless sideroblasts had been seen and this was only possible because of the previous excessive parenteral iron treatment. It is thus possible that some of the patients with adult coeliac disease reported by French, Hawkins, and Smith (1957), who had a persistent mild anaemia in spite of treatment with iron, folic acid, and vitamin $B_{12}$ and only had a full haematological response after treatment with a gluten-free diet, did in fact have pyridoxine deficiency. Moreover, although the body iron stores were greatly increased, the initial serum iron was low, and, had the marrow not been examined for iron, this finding 
would have been accepted as confirming the presence of a typical iron deficiency anaemia due to malabsorption. With so severe a protein deficiency, impaired synthesis of transferrin might be the cause of a low serum iron level but, although the ironbinding capacity was low, it was less than $30 \%$ saturated. However, the serum iron tends to fall in all patients with infections or severe metabolic disturbances and such a fall may also occur even when the iron stores are increased in association with a sideroblastic anaemia (Björkman, 1959). On admission, this patient was gravely ill and with clinical improvement both the serum iron and ironbinding capacity increased, finally reaching the characteristic levels seen in patients with iron overload.

The deficiency states arising in adult coeliac disease are usually due to a combination of impaired absorption and poor dietary intake, for such patients often have profound anorexia. Yet even in patients on apparently similar diets and with a similar degree of small bowel involvement the predominant manifestation of the disease may be extremely varied ranging from megaloblastic anaemia to osteomalacia and hypoproteinanaemia to dermatitis. This may well be due to the large variation in the individual requirements of various vitamins and amino-acids (Williams, 1956).

We would like to thank Dr. David Mollin for advice and for performing the xanthurenic and folic acid estimations.

\section{REFERENCES}

Björkman, S. E. (1959). Anaemia refractoria sideroblastica. In Eisenstoffwechsel, edited by W. Keiderling, pp. 234-237. Thieme, Stuttgart.

Booth, C. C., and Brain, M. C. (1962). The absorption of tritiumlabelled pyridoxine hydrochloride in the rat. J. Physiol. (Lond.) 164, 282-294.
Bowman, W. D., Jr. (1961). Abnormal ('ringed') sideroblasts in various hematologic and non-hematologic disorders. Blood, 18, 662-671.

Brain, M. C., Stewart, J. S., and Booth, C. C. (1963). The absorption of tritiated pyridoxine in the rat and in man. Radioaktive isotope in Klinik und Forschung, 5, 475-483.

Braunstein, A. E. (1960). In The Enzymes, 2nd ed., vol. 2, edited by P. D. Boyer, H. Lardy, and K. Myrback, pp. 113-184. Academic Press, New York.

Dacie, J. V., Smith, M. D., White, J. C., and Mollin, D. L. (1959). Refractory normoblastic anaemia: a clinical and haematological study of seven cases. Brit. J. Haemat. 5, 56-82.

Ernslev, A. J., Lear, A. A., and Castle, W. B. (1960). Pyridoxineresponsive anaemia. New Engl. J. Med. 262, 1209-1214.

Follis, R. H., Jr. (1958). Deficiency Disease, pp. 235-249. Thomas, Springfield, Illinois.

French, J. M., Hawkins, C. F., and Smith, N. (1957). The effect of a wheat-gluten-free diet in adult idiopathic steatorrhoea. Quart. J. Med., n.s., 26, 481-499.

Girdwood, R. H. (1959). The role of folic acid in blood disorders. Brit. med. Bull. 15, 14-18.

Heilmeyer, L., Keiderling, W., Bilger, R., and Bernauer, H. (1958). Uber chronische refrakt Anämien nut sideroblastischem Knochenmark (Anaemia refractoria sideroblastica). Folia haemat., (Frankfurt). 2, 49-60.

Kohn, R., Heilmeyer, L., and Clotten, R. (1963). Pyridoxine-responsive sideroachrestic anaemia in the course of isoniazid treatment, Germ. med. Mth. 8, 103-107.

Kowlessar, O. D., Haeffner, L. J., Benson, G., and Sleisenger, M. H. (1961). Evidence for deficiency of vitamin B6 in non-tropical sprue. J. clin. Invest., 40, 1055 (Abst).

Mirone, L. and Jackson, C. D. (1959). The development and cure of pyridoxine deficiency symptoms in weanling mice. J. Nutr. 67. 167-180.

Mollin, D. L., and Dacie, J. V. (1960). Further observations on refractory normoblastic anaemia, Part 2. Proc. 7th Congr. Europ. Soc. Haemat., London, 1959, pp. 74-78. Karger, Basel.

Molony, C. J., and Parmelee, A. H. (1954). Convulsions in young infants as a result of pyridoxine (Vitamin B6) deficiency. $J$. Amer. med. Ass., 154, 405-406.

Mueller, J. F. and Vilter, R. W. (1950). Pyridoxine deficiency in human beings induced with desoxypyridoxine. J. clin. Invest. 29, 193-201.

Rabinowitz, J. C. and Snell, E. E. (1948). Distribution of pyridoxal, pyridoxamine, and pyridoxine in some natural products. J. biol. Chem., 176, 1157-1167.

Rosen, D. A., Maengwyn-Davies, G. D., Becker, B., Stone, H. H., and Friedenwald, J. S. (1955). Xanthurenic acid excretion studies in diabetes with and without retinopathy. Proc. Soc. exp. Biol. (N. Y.), 88, 321-323.

Wachstein, M. and Lobel, S. (1954). Abnormal tryptophan metabolites in human pregnancy and their relation to deranged Vitamin B6 metabolism. Ibid. 86, 624-627.

Wells, G. C. (1962). Skin disorders in relation to malabsorption. Brit. med. J. 2, 937-943.

Williams, R. J. (1956). Biochemical Individuality. Wiley, New York. 